\title{
Preparation of Soymilk Using Different Methods
}

\author{
M. F. Afroz ${ }^{1}$, Wasima Anjum ${ }^{2}$, Md. NurulIslam ${ }^{2}$, Md. Ahsanul Kobir ${ }^{1}$, Kaiyum Hossain ${ }^{3}$, \\ Abu Sayed ${ }^{4}$, * \\ ${ }^{1}$ Department of Biotechnology, Bangladesh Livestock Research Institute, Savar, Dhaka, Bangladesh \\ ${ }^{2}$ Department of Dairy Science, Bangladesh Agricultural University, Mymensingh, Bangladesh \\ ${ }^{3}$ Biman Poultry Complex, Gonakbari, Savar, Dhaka, Bangladesh \\ ${ }^{4}$ Department of Agricultural Engineering, EXIM Bank Agricultural University Bangladesh, Chapainawabgonj, Bangladesh
}

\section{Email address:}

abu_982@yahoo.com (A. Sayed)

\section{To cite this article:}

M. F. Afroz, Wasima Anjum, Md. Nurul Islam, Md. Ahsanul Kobir, Kaiyum Hossain, Abu Sayed. Preparation of Soymilk Using Different Methods. Journal of Food and Nutrition Sciences. Vol. 4, No. 1, 2016, pp. 11-17. doi: 10.11648/j.jfns.20160401.13

\begin{abstract}
The present experiment was conducted to prepare soymilk from whole soya seed by using various techniques. Twelve (12) soymilk samples were prepared by three different methods with four concentration level. Each sample was analyzed for proximate composition and sensory qualities were evaluated by a taste panel. No significant difference was found between dehulled soy seed blending milk and whole soy seed powder milk. But $125 \mathrm{~g}$ concentration obtained highest score from the judges. From the results of chemical analysis, significant difference was found in terms of moisture, total solids, solids- not- fat, protein, fat, carbohydrate, ash content and acidity percentage. Dehulled soy seed blending milk contained more moisture, protein, fat and ash content. On the other hand, a sharp increase of nutrient concentration was observed with the increase of soymilk concentration. But soymilk of 150 and $175 \mathrm{~g}$ concentration become thicker after boiling which had fewer acceptances by the judges. Considering the physical and chemical properties of all samples, it is recommended that $125 \mathrm{~g}$ concentrate dehulled soy seed blending milk may be prepared in industrial scale.
\end{abstract}

Keywords: Soya Seed, Soymilk, Organoleptic Score and Sensory Quality

\section{Introduction}

Milk is the nature's most nearly perfect food for the newly born infant or animal and for all ages of people. But, there is an acute shortage of milk and other protein rich food of animal origin in Bangladesh. Consequently the incidence of protein malnutrition is very high among preschool children, expectant and nursing mothers. For this purpose, low cost processed supplementary protein rich food need to be developed in Bangladesh [1]. Soybean has been recognized as one of the premier agricultural crops today for various reasons in the world [2]. Now-a-day different types of human foods are prepared from soybean such as soymilk, tofu, Ice cream, beverage etc [3]. Oil and protein rich soybean has now recognized all over the world as a potential supplementary source of edible oil and nutrition [4]. Soymilk is a rich creamy milk of whole soybeans. The nutrients content in eight ounces of plain soymilk are $140 \mathrm{gm}$ calories, $10 \mathrm{gm}$ protein, $4 \mathrm{gm}$ fat, $14 \mathrm{gm}$ carbohydrate, $120 \mathrm{~g}$ sodium, $1.8 \mathrm{mg}$ iron, $0.1 \mathrm{mg}$ riboflavin and $80 \mathrm{mg}$ calcium [5]. Soymilk is free of milk sugar lactose and for this reason there is no chance of occurring lactose intolerance syndrome. Also, it is good alternative for those who are allergic to cow's milk. It naturally has about the same amount of protein (but not the same proteins) as cow milk.

Soybean can play a vital role in balancing the protein deficiency of our diet. Protein content of soybean is about 2 times of other pulses, 4 times of wheat, 6 times of rice grain, 4 times of egg; 12 times of milk. Soybean has 3\% lecithin, which is helpful for brain development. It is also rich in $\mathrm{Ca}$, Protein and Vitamins A, B, C and D [2]. In countries or regions where animal protein are not available or where the price of meat are beyond the purchasing power of average population, soybean and soybean products may be used as their substitutes. Unfortunately no published/unpublished information is available on the preparation of soymilk under Bangladesh condition. This indicates that systematic research work in this line is urgently needed to develop technique for making soymilk. For this reason the present research work was conducted to prepare soymilk using different methods and to recommend 
a suitable method for soymilk preparation and to evaluate the physical and chemical qualities of soymilk.

\section{Materials and Methods}

\subsection{Collection of Soybean Seed}

The study was conducted at the Dairy Technology and Microbiology Laboratory of the Department of Dairy Science, Bangladesh Agricultural University, Mymensingh during the period of lst February to 30th May, 2012. High quality wholesome and mature soybean seeds were purchased from local markets of Trishal Upazilla of Mymensingh District. After sun drying the seeds were kept in airtight plastic containers for experimental purpose.

\subsection{Methods of Preparation}

Soymilk was prepared in the Laboratory using following 3 (three) methods: I. Preparation of soymilk from dehulled soybean by blending method, II. Preparation of soymilk from whole soybean powder and III. Preparation of soymilk from dehulled sundry soybean powder. In each methods four concentration of soy seeds were used. The concentrations were $100,125,150$ and $175 \mathrm{~g}$ soybean in different forms $/ 1000 \mathrm{ml}$ of milk. Three trials were given during the experimental period. The results obtained for various parameters studied from different types of soymilk with different concentration during the experiment are presented in this section.

\subsubsection{Preparation of Soymilk from Dehulled Soybean by Blending Method}

The clean fresh 550 gm soybean seeds were taken and they were divided into four parts, having 100, 125, 150 and $175 \mathrm{~g}$ in each part respectively. They were soaked separately in water for 10-12 hours or overnight. Small amount of sodium bicarbonate $(0.3 \%)$ were added with water. The main purpose of using sodium bicarbonate was to remove the bitterness and anti-nutritional factors (trypsin inhibitor). Soaked soybean's husk were removed by means of pressure of two hands and cleaned with continuous flow of fresh water. Then clean dehulled soybeans were ground with $1000 \mathrm{ml}$ of water separately by blending machine for 10-15 min at low speed to prepare $100,125,150$, and $175 \mathrm{~g}$ concentrate soymilk. The homogenized mass was strained through a fine cloth to separate milk from residue. Soymilk was then boiled at $100^{\circ} \mathrm{C}$ for $10-15$ minutes with constant stirring.

\subsubsection{Preparation of Soymilk from Whole Soybean Powder}

$1000 \mathrm{gm}$ whole soybean free from immature field damage and black spot were grinded in a soy flour mill 100g, 125g, $150 \mathrm{~g}$ and $175 \mathrm{~g}$ powder was dissolved with $1000 \mathrm{ml}$ of water respectively by stirring. The milk was strained through a fine cloth to separate the residue. Soymilk was then boiled at $100^{\circ} \mathrm{C}$ for $10-15$ minutes with constant stirring.

\subsubsection{Preparation of Soymilk from Dehulled Sundry Soybean Powder}

Dry whole soybean were cleaned, washed and soaked in tap water overnight in 4 times of weight $(\mathrm{w} / \mathrm{v})$ with $0.3 \%$ sodium bicarbonate. After decanting the soak water, the beans were washed again with fresh tap water. Soaked soybean's husk were removed by means of pressure of two hands and cleaned with continues flow of fresh tap water. After wash the soybean seed was sun dried to its original moisture content. The sundried dehulled soybean was grinded in a soy flour mill $100 \mathrm{~g}, 125 \mathrm{~g}, 150 \mathrm{~g}$ and $175 \mathrm{~g}$ powder was dissolved with $1000 \mathrm{ml}$ of water respectively by stirring. The milk was strained through a fine cloth to separate the residue. Soymilk was then boiled at $100^{\circ} \mathrm{C}$ for $10-15$ minutes with constant stirring.

\subsection{Chemical and Physical Analysis}

Physical tests (Smell, color \& appearance, texture and sediment taste) were performed organoleptically with the help of an expert panel of judge by using a score card. Chemical tests (Moisture content, total solids content and solids- not- fat content) were done in the Dairy Technology Laboratory, Department of Dairy Science. Moisture content, total solids content, Protein, acidity percentage, ash content and fat percentage were determined by the method suggested as per method described by [6]. On the other hand, carbohydrate content and solids- not- fat content were determined by the calculating method.

\subsection{Statistical Analysis}

Main effect in this experiment was three methods and within each method there were four concentration levels. For this reason data was analyzed by using $3 \times 4$ factorial experiments. Analysis of variance tests were performed to find out the statistical difference within treatments and each case of significant difference LSD test was carried out to compare the mean values of different treatment.

\section{Results and Discussion}

\subsection{Smell and Taste}

The average smell and taste score of dehulled soy seed blending milk (A), Whole soy seed powder milk (B) and sundry dehulled soy seed powder milk (C) type soymilk were $38.59 \pm 0.77,41.0 \pm 0.3$ and $33.99 \pm 0.62$ respectively (Table 1 ). From the statistical analysis it was found that the smell and taste score of A, B and C type soymilk samples differ significantly $(p<0.01)$. From the table it was found that $B$ type soymilk has highest smell and taste score and lowest in case of $\mathrm{C}$. The result indicates that method of soymilk preparation affect the smell and taste score. 
Table 1. Average value of chemical composition of different types of soymilk.

\begin{tabular}{|c|c|c|c|c|c|}
\hline \multirow{2}{*}{ Sources of variation } & \multicolumn{3}{|c|}{ Types of soymilk } & \multirow{2}{*}{ LSD/SED value } & \multirow{2}{*}{$\begin{array}{l}\text { Level of } \\
\text { significance }\end{array}$} \\
\hline & $\mathbf{A}$ & B & $\mathbf{C}$ & & \\
\hline Smell and taste & $38.59^{\mathrm{b}} \pm 0.77$ & $41.0^{\mathrm{a}} \pm 0.30$ & $33.99^{\mathrm{c}} \pm 0.62$ & 1.59 & $* *$ \\
\hline Color and Appearance (20) & $15.84^{\mathrm{a}} \pm 0.87$ & $15.17^{\mathrm{a}} \pm 0.32$ & $12.08^{\mathrm{b}} \pm 0.42$ & 1.56 & $* *$ \\
\hline Texture (20) & $15.91^{\mathrm{a}} \pm 0.62$ & $16.17^{\mathrm{a}} \pm 0.64$ & $12.92^{\mathrm{b}} \pm 0.49$ & 1.59 & $* *$ \\
\hline Sediment (10) & $7.99^{\mathrm{a}} \pm 0.23$ & $6.75^{\mathrm{b}} \pm 0.52$ & $5.4^{\mathrm{c}} \pm 0.42$ & 1.07 & $* *$ \\
\hline Overall score (100) & $78.33^{\mathrm{a}} \pm 2.48$ & $79.17^{\mathrm{a}} \pm 1.75$ & $64.25^{\mathrm{b}} \pm 1.94$ & 5.49 & $* *$ \\
\hline
\end{tabular}

Means with different superscript in the same row differ significantly $(\mathrm{p}<0.05), * *=1 \%$ level of significance, where, $\mathrm{A}=$ Dehulled soy seed blending milk, $\mathrm{B}=$ Whole soy seed power milk and $\mathrm{C}=$ Sundry dehulled soy seed power milk.

Table 2. Average value of chemical composition of different concentration of soymilk.

\begin{tabular}{|c|c|c|c|c|c|c|}
\hline \multirow{2}{*}{ Sources of variation } & \multicolumn{4}{|c|}{ Concentration of soymilk } & \multirow{2}{*}{ LSD/SED value } & \multirow{2}{*}{ L.S } \\
\hline & 1 & 2 & 3 & 4 & & \\
\hline Smell and taste & $38.77^{\mathrm{a}} \pm 1.79$ & $38.55^{\mathrm{a}} \pm 2.32$ & $37.65^{\mathrm{ab}} \pm 1.85$ & $36.44^{\mathrm{b}} \pm 2.31$ & 3.46 & $* *$ \\
\hline Color and Appearance (20) & $15.00^{\mathrm{a}} \pm 1.07$ & $15.33^{\mathrm{a}} \pm 1.58$ & $14.00^{\mathrm{b}} \pm 1.02$ & $13.11^{\mathrm{c}} \pm 1.09$ & 2.03 & $* *$ \\
\hline Texture (20) & $15.67^{\mathrm{a}} \pm 0.84$ & $16.11^{\mathrm{a}} \pm 1.39$ & $14.67^{\mathrm{b}} \pm 1.0$ & $13.55^{\mathrm{c}} \pm 0.95$ & 1.77 & $* *$ \\
\hline Sediment (10) & $7.4^{\mathrm{a}} \pm 0.58$ & $7.1^{\mathrm{a}} \pm 0.78$ & $6.7^{\mathrm{b}} \pm 0.78$ & $5.7^{\mathrm{c}} \pm 0.88$ & 1.27 & $* *$ \\
\hline Overall score (100) & $77.0^{\mathrm{a}} \pm 4.17$ & $77.11^{\mathrm{a}} \pm 5.89$ & $72.78^{\mathrm{b}} \pm 4.6$ & $68.78^{c} \pm 4.80$ & 8.15 & $* *$ \\
\hline
\end{tabular}

Means with different superscript in the same row differ significantly $(\mathrm{p}<0.05), * *=1 \%$ level of significance, where, $1=100 \mathrm{~g} / 1000 \mathrm{ml}$ of water, $2=$ $125 \mathrm{~g} / 1000 \mathrm{ml}$ of water, $3=150 \mathrm{~g} / 1000 \mathrm{ml}$ of water and $4=175 \mathrm{~g} / 1000 \mathrm{ml}$ of water.

On the other hand smell and taste score of 100, 125, 150 and $175 \mathrm{~g}$ concentration soymilk (i.e. 1, 2, 3 and 4) were $38.77 \pm 1.79,38.55 \pm 2.32,37.65 \pm 1.85$ and $36.44 \pm 2.31$ (Table 2) respectively. Statistical analysis showed that there was significant difference within the smell and taste score of different concentration. Highest score was found for $100 \mathrm{~g}$ and lowest score for $175 \mathrm{~g}$ concentration soymilk. The result indicates smell and taste score decreased with increased concentration of soybean because beany flavor increased. The interaction effects of method and concentration level were non-significant. Smell and Taste score of A1, A2, A3, $\mathrm{A} 4, \mathrm{~B} 1, \mathrm{~B} 2, \mathrm{~B} 3, \mathrm{~B} 4, \mathrm{C} 1, \mathrm{C} 2, \mathrm{C} 3$ and $\mathrm{C} 4$ were $39.67 \pm 0.88$, $40 \pm 0.58, \quad 38.0 \pm 0.58, \quad 36.67 \pm 1.45, \quad 41.33 \pm 0.33,41.33 \pm 0.33$, 41.67 $\pm 0.67 .40 .67 \pm 0.33,40.33 \pm 0.33,35.33 \pm 0.33,34.0 \pm 0.58$, $34.33 \pm 0.88$ and $32.33 \pm 0.88$ respectively (Table 3 ). The result of interaction effects indicates that highest smell and taste score was obtained in B2 combination(i.e. Whole soy seed powder milk and $125 \mathrm{~g}$ concentration) and lowest score was obtained in C4 combination (Sundry dehulled soy seed powder milk and $175 \mathrm{~g}$ concentration).

Table 3. Average score of various organoleptic characteristics of different types of soymilk different concentration.

\begin{tabular}{|c|c|c|c|c|c|c|c|c|}
\hline \multirow{2}{*}{ Sources of variation } & \multicolumn{8}{|c|}{ Types of soymilk } \\
\hline & A1 & $\mathbf{A 2}$ & A3 & A4 & B1 & B2 & B3 & B4 \\
\hline Smell and taste (50) & $39.67 \pm 0.88$ & $40.00 \pm 0.58$ & $38.00 \pm 0.58$ & $36.67 \pm 1.45$ & $41.33 \pm 0.33$ & $41.67 \pm 0.67$ & $40.67 \pm 0.33$ & $40.33 \pm 0.33$ \\
\hline $\begin{array}{l}\text { Color and } \\
\text { Appearance (20) }\end{array}$ & $16.67 \pm 0.33$ & $17.67 \pm 0.33$ & $15.33 \pm 0.88$ & $13.67 \pm 0.67$ & $15.33 \pm 0.33$ & $16.00 \pm 0.58$ & $14.67 \pm 0.33$ & $14.67 \pm 0.33$ \\
\hline Texture (20) & $16.33 \pm 0.33$ & $17.33 \pm 0.33$ & $15.67 \pm 0.67$ & $14.33 \pm 0.33$ & $16.67 \pm 0.33$ & $17.67 \pm 0.33$ & $15.67 \pm 0.33$ & $14.67 \pm 0.33$ \\
\hline Sediment (10) & $8.30 \pm 0.33$ & $8.30 \pm 0.33$ & $8.00 \pm 0.33$ & $7.30 \pm 0.00$ & $7.60 \pm 0.33$ & $7.30 \pm 0.33$ & $6.70 \pm 0.33$ & $5.30 \pm 0.33$ \\
\hline Overall score (100) & $81.0 \pm 0.57$ & $83.33 \pm 0.33$ & $77.00 \pm 1.00$ & $72.00 \pm 1.53$ & $81.33 \pm 0.33$ & $82.67 \pm 0.67$ & $77.67 \pm 0.67$ & $75.00 \pm 0.58$ \\
\hline
\end{tabular}

Table 3. Continued.

\begin{tabular}{lllllll}
\hline \multirow{2}{*}{ Sources of variation } & \multicolumn{2}{l}{ Types of soymilk } & & SED value & $\begin{array}{l}\text { Level of } \\
\text { significance }\end{array}$ \\
\cline { 2 - 6 } & C1 & C2 & C3 & C4 & NS \\
Smell and taste (50) & $35.33 \pm 0.33$ & $34.00 \pm 0.58$ & $34.33 \pm 0.88$ & $32.33 \pm 0.88$ & 0.29 & NS \\
Color and Appearance (20) & $13.00 \pm 0.00$ & $12.33 \pm 0.33$ & $12.00 \pm 0.58$ & $11.00 \pm 0.58$ & 0.35 & NS \\
Texture (20) & $14.00 \pm 0.00$ & $13.33 \pm 0.33$ & $12.67 \pm 0.33$ & $11.60 \pm 0.33$ & 0.15 & NS \\
Sediment (10) & $6.3 \pm 0.33$ & $5.70 \pm 0.33$ & $5.30 \pm 0.33$ & $4.30 \pm 0.33$ & 0.13 & NS \\
Overall score (100) & $68.67 \pm 0.67$ & $65.33 \pm 1.33$ & $63.67 \pm 0.67$ & $59.33 \pm 1.33$ & 0.36 & \\
\hline
\end{tabular}

Means with different superscript in the same row differ significantly $(\mathrm{p}<0.01), *=5 \%$ level of significance and $* *=1 \%$ level of significance, where, $\mathrm{A}=$ Dehulled soy seed blending milk, $\mathrm{B}=$ Whole soy seed power milk and $\mathrm{C}=$ Sundry dehulled soy seed power milk and $1=100 \mathrm{~g} / 1000 \mathrm{ml}$ of water, $2=$ $125 \mathrm{~g} / 1000 \mathrm{ml}$ of water, $3=150 \mathrm{~g} / 1000 \mathrm{ml}$ of water and $4=175 \mathrm{~g} / 1000 \mathrm{ml}$ of water.

From the analyses of the results of different combinations of method and concentration it was found that different method and concentration had significant effect on smell and taste score but interaction effects had no significant effect on smells and taste score. From the results it is clear that judges prefer B method and for this reason score was highest, second highest score was for A method of soymilk. Escuetaand Banzon [7] stated that addition of $1 \%$ chocolate 
powder increased further acceptability of the soymilks. Unfortunately nopublished information has come in attention to author in relation to method and concentration level. For this reason, it was not possible to compare the data obtained from this study with other workers.

\subsection{Texture}

The average texture score of soymilk prepared by different methods and concentration are shown in (Table 1). It was found that the average texture score of $\mathrm{A}, \mathrm{B}$ and $\mathrm{C}$ type soymilk were $15.91 \pm 0.62, \quad 16.17 \pm 0.64 ; \quad 12.92 \pm 0.49$, respectively. Lowest score was seen in $\mathrm{C}$ type milk. But there was no-significant difference between A and B type soymilk. The result indicates that method of soymilk preparation affect the texture score. Texture score of $100,125,150$ and $175 \mathrm{~g}$ concentration soymilk (i.e. 1, 2, 3 and 4) were $15.67 \pm 0.84$, $16.11 \pm 1.39,14.67 \pm 1.0$ and $13.55 \pm 0.95$ respectively. Highest score was secured by $125 \mathrm{~g}$ concentration soymilk and lowest score was obtained by 175 gconcentration soymilk.

The result of interaction effects (Table 3)indicates that highest texture score was obtained in B2 combination(i.e. whole soy seed powder milk and $125 \mathrm{~g}$ concentration) and lowest score was obtained in $\mathrm{C} 4$ combination (Sundry dehulled soy seed powder milk and 175 gconcentration).From the analyses of the results of different combinations of method and concentration it was found that different method and concentration had significant effect on texture score but interaction effects had no significant effect on texture score.

\subsection{Sediment}

The average sediment score of A, B and C type soymilk were $7.99 \pm 0.23,6.75 \pm 0.52,5.4 \pm 0.42$ respectively (Table 1 ). Highest score was recorded in A type milk and lowest score was seen in $\mathrm{C}$ type milk. But there was no significant difference between $\mathrm{B}$ and $\mathrm{C}$ type soymilk. Average sediment score of 100, 125, 150 and $175 \mathrm{~g}$ concentration soymilk (i.e. 1, 2, 3 and 4$)$ were $7.4 \pm 0.58,7.1 \pm 0.78,6.7 \pm 0.78$ and $5.7 \pm 0.88$ respectively (Table 2). Highest score was secured by $100 \mathrm{~g}$ concentration soymilk and lowest score was obtained by $175 \mathrm{~g}$ concentration soymilk.

The result of interaction effects indicates that highest sediment score was obtained in B1 and B2 combination (i.e. Dehulled soy seed blending milk with $100 \mathrm{~g}$ and $125 \mathrm{~g}$ concentration) and lowest score was obtained in combination C4 (Sundry dehulled soy seed powder milk and 175 gconcentration).From the results it is clear that judges prefer A method and for this reason score was highest, second highest score was for B method of soymilk.

\subsection{Overall Score}

Overall score of different types of soymilk such as A, B and $\mathrm{C}$ were $78.33 \pm 2.48, \quad 79.17 \pm 1.75$ and $64.25 \pm 1.94$ respectively (Table 1).Statistical analysis showed that was no significant difference between A and B type soymilk. Overall score of $100,125,150$ and $175 \mathrm{~g}$ concentration soymilk (i.e. $1,2,3$ and 4) were 77.0 $\pm 4.17,77.11 \pm 5.89,72.78 \pm 4.56$ and $68.78 \pm 4.80$ respectively (Table 2 ). Highest score was secured by $125 \mathrm{~g}$ concentration soymilk and lowest score was obtained by $175 \mathrm{~g}$ concentration soymilk. No significant difference was found between 100 and $125 \mathrm{~g}$ concentration soymilk. The interaction effects of method and concentration level on overall score was non-significant $(\mathrm{p}<0.01)$. It was found that overall score were $81.0 \pm 0.57$, $83.33 \pm 0.33,77.0 \pm 1.00,72.0 \pm 1.53,81.33 \pm 0.33,82.67 \pm 0.67$, $77.67 \pm 0.67,75.0 \pm 0.58,68.67 \pm 0.67,65.33 \pm 1.33,63.67 \pm 0.67$ and $59.33 \pm 1.33$ for $\mathrm{A} 1, \mathrm{~A} 2, \mathrm{~A} 3, \mathrm{~A} 4, \mathrm{~B} 1, \mathrm{~B} 2, \mathrm{~B} 3, \mathrm{~B} 4, \mathrm{Cl}, \mathrm{C} 2$, $\mathrm{C} 3$ and $\mathrm{C} 4$ respectively (Table 4,3 ).Highest score is obtained in A2 combination.

\subsection{Chemical Analysis}

\subsubsection{Moisture Content}

The moisture contents of A, B and C type soymilk were903.86 $\pm 10.72, \quad 892.23 \pm 12.22$ and $907.32 \pm 1054(\mathrm{~g} / \mathrm{kg})$ respectively (Table 4). From the results, it is evident that there was significant difference within the moisture content of different type of soymilk. Highest moisture content was in $\mathrm{C}$ type milk. But no significant difference was found between A and $\mathrm{C}$ type soy milk. On the other hand moisture content of $100,125,150$ and $175 \mathrm{~g}$ concentration soymilk (i.e. 1, 2, 3 and 4) were $927.05 \pm 3.34,909.82 \pm 4.16,892.45 \pm 4.95$ and $875.20 \pm 5.81(\mathrm{~g} / \mathrm{kg})$ respectively (Table 5). Average moisture content of different types of soymilk with different concentration is shown in Table 6.The effect of concentration level on moisture content of soymilk was significant. Plernchai [8] found 91.4\% moisture in soymilk.

Table 4. Average value of chemical composition of different types of soymilk.

\begin{tabular}{|c|c|c|c|c|c|}
\hline \multirow{2}{*}{ Sources of variation } & \multicolumn{3}{|c|}{ Types of soymilk } & \multirow{2}{*}{ LSD/SED value } & \multirow{2}{*}{ Level of significance } \\
\hline & $\mathbf{A}$ & B & $\mathrm{C}$ & & \\
\hline Moisture (g/kg & $903.86^{\mathrm{a}} \pm 10.72$ & $892.23^{b} \pm 12.22$ & $907.32^{\mathrm{a}} \pm 10.54$ & 29.67 & ** \\
\hline Total solids $(\mathrm{g} / \mathrm{kg})$ & $96.15^{\mathrm{b}} \pm 10.72$ & $107.75^{\mathrm{a}} \pm 12.20$ & $92.75^{\mathrm{b}} \pm 10.51$ & 29.64 & ** \\
\hline S.N.F. $(\mathrm{g} / \mathrm{kg})$ & $61.37^{b} \pm 7.26$ & $77.33^{\mathrm{a}} \pm 9.08$ & $63.23^{b} \pm 7.32$ & 21.13 & ** \\
\hline Protein $(\mathrm{g} / \mathrm{kg})$ & $38.75^{\mathrm{a}} \pm 4.5$ & $37.81^{\mathrm{a}} \pm 4.44$ & $34.83^{\mathrm{b}} \pm 1.08$ & 11.57 & ** \\
\hline Fat $(\mathrm{g} / \mathrm{kg})$ & $29.83^{\mathrm{a}} \pm 2.33$ & $26.25^{\mathrm{b}} \pm 3.07$ & $25.75^{\mathrm{b}} \pm 2.99$ & 8.42 & ** \\
\hline Carbohydrate (g/kg) & $20.97^{c} \pm 2.54$ & $38.14^{\mathrm{a}} \pm 4.47$ & $26.99^{\mathrm{b}} \pm 3.21$ & 9.26 & $* *$ \\
\hline $\operatorname{Ash}(\mathrm{g} / \mathrm{kg})$ & $6.54^{\mathrm{a}} \pm 0.21$ & $5.55^{\mathrm{b}} \pm 0.22$ & $5.10^{\mathrm{c}} \pm 0.25$ & 0.42 & $* *$ \\
\hline Acidity (\%) & $0.17^{\mathrm{a}} \pm 0.02$ & $0.15^{\mathrm{b}} \pm 0.02$ & $0.13^{c} \pm 0.02$ & 0.065 & ** \\
\hline $\mathrm{pH}$ & $6.6 \pm 0.08$ & $6.7 \pm 0.0$ & $6.6 \pm 0.04$ & 0.04 & NS \\
\hline
\end{tabular}

Means with different superscript in the same row differ significantly $(\mathrm{p}<0.05), * *=1 \%$ level of significance, $\mathrm{NS}=$ Non significant, where, $\mathrm{A}, \mathrm{B}, \mathrm{C}=$ same the meaning which are previously stated. 
Table 5. Average value of chemical composition of different concentration of soymilk.

\begin{tabular}{|c|c|c|c|c|c|c|}
\hline \multirow{2}{*}{ Sources of variation } & \multicolumn{4}{|c|}{ Concentration of soymilk } & \multirow{2}{*}{ LSD/SED value } & \multirow{2}{*}{ Level of significance } \\
\hline & 1 & 2 & 3 & 4 & & \\
\hline Moisture $(\mathrm{g} / \mathrm{kg}$ & $927.05 \mathrm{a} \pm 3.34$ & $909.82 b \pm 4.16$ & $892.45 c \pm 4.95$ & $875.20 \mathrm{~d} \pm 5.81$ & 7.76 & $* *$ \\
\hline Total solids (g/kg) & $72.95 \mathrm{~d} \pm 3.34$ & $90.18 \mathrm{c} \pm 4.26$ & $107.54 \mathrm{~b} \pm 4.94$ & $124.73 \mathrm{a} \pm 5.80$ & 7.75 & $* *$ \\
\hline S.N.F. $(\mathrm{g} / \mathrm{kg})$ & $49.00 \mathrm{~d} \pm 3.68$ & $61.09 \mathrm{c} \pm 4.57$ & $73.35 b \pm 5.52$ & $85.81 \mathrm{a} \pm 6.37$ & 8.56 & $* *$ \\
\hline Protein $(\mathrm{g} / \mathrm{kg})$ & $27.00 \mathrm{~d} \pm 0.85$ & $33.75 \mathrm{c} \pm 1.07$ & $40.51 \mathrm{~b} \pm 1.28$ & $47.26 \mathrm{a} \pm 1.50$ & 2.00 & $* *$ \\
\hline Fat $(\mathrm{g} / \mathrm{kg})$ & $19.78 \mathrm{~d} \pm 0.94$ & $25.00 \mathrm{c} \pm 1.17$ & $29.78 b \pm 1.45$ & $34.56 \mathrm{a} 1.57$ & 2.18 & $* *$ \\
\hline Ash (g/kg) & $5.24 \mathrm{~d} \pm 0.44$ & $5.50 \mathrm{c} \pm 0.46$ & $5.90 \mathrm{~b} \pm 0.39$ & $6.24 \mathrm{a} \pm 0.41$ & 0.71 & $* *$ \\
\hline Acidity (\%) & $0.10 \mathrm{~d} \pm 0.02$ & $0.133 \mathrm{c} \pm 0.00$ & $0.17 \mathrm{~b} \pm 0.12$ & $0.20 \mathrm{a} \pm 0.02$ & 0.07 & $* *$ \\
\hline $\mathrm{pH}$ & $6.60 \pm 0.03$ & $6.60 \pm 0.03$ & $6.70 \pm 0.05$ & $6.50 \pm 0.09$ & 0.12 & NS \\
\hline
\end{tabular}

Means with different superscript in the same row differ significantly $(\mathrm{p}<0.05), * *=1 \%$ level of significance, $\mathrm{NS}=\mathrm{Non}$ significant, where, $\mathrm{A}, \mathrm{B}, \mathrm{C}=$ same the meaning which are previously stated.

\subsubsection{Total Solids Content}

Table 4 showed that mean total solids content of A, B and C type soymilk were96.15 $\pm 10.72,107.75 \pm 12.20$ and $92.75 \pm 10.51(\mathrm{~g} / \mathrm{kg})$ respectively. From this table it was observed that total solids contents of B type soymilk were highest. Total solids contents were decreased in A and C type soymilk. It might be due to the variation in moisture content of soymilk prepared by different method. On the other hand total solids content of 100,125, 150 and 175 gconcentration soymilk (i.e. 1, 2, 3 and 4) were $72.95 \pm 3.34,90.18 \pm 4.26$, $107.54 \pm 4.94$ and $124.73 \pm 5.80(\mathrm{~g} / \mathrm{kg})$ respectively (Table 5). The effect of concentration level on total solids of soymilk was significant. Average total solids of different types of soymilk with different concentration are shown in Table 6. [9] Stated that soymilk contain $12.25 \%$ of total solids.

\subsubsection{Solids-Not-Fat Content}

The average solids-not-fat content of soymilk prepared by different methods and concentration were shown in Table 4 to 5. The average solid not fat content of A, B and C type soymilk were $61.37 \pm 7.26,77.33 \pm 9.08$ and $63.23 \pm 7.42(\mathrm{~g} / \mathrm{kg})$ respectively. Solids not fat content in A, B and C type soymilk differ significantly. From the table it is observed that solids not fat content was highest in B type soymilk followed by $\mathrm{C}$ and A type. So it can be concluded that the solids not fat content of soymilk was influenced by method of preparation. On the other hand solid-not-fat content of 100, 125, 150 and $175 \mathrm{~g}$ concentration soymilk (i.e. 1, 2, 3 and 4) were $49.00 \pm 3.68,61.09 \pm 4.57,73.35 \pm 5.52$ and $85.81 \pm 6.37(\mathrm{~g} / \mathrm{kg})$ respectively. The effect of concentration level on solids not fat content of soymilk was significant.

Table 6. Average value of chemical composition of different types of soy milk with different concentration.

\begin{tabular}{|c|c|c|c|c|c|c|c|c|}
\hline \multirow{2}{*}{$\begin{array}{l}\text { Sources of } \\
\text { variation }\end{array}$} & \multicolumn{8}{|c|}{ Types of soymilk } \\
\hline & A1 & $\mathbf{A 2}$ & A3 & A4 & B1 & B2 & B3 & B4 \\
\hline Moisture (g/kg) & $928.77 \pm 1.45$ & $912.17 \pm 1.83$ & $895.53 \pm 2.13$ & $878.93 \pm 2.50$ & $920.60 \pm 2.41$ & $901.73 \pm 3.03$ & $882.77 \pm 3.61$ & $863.80 \pm 4.26$ \\
\hline T. Solids (g/kg) & $71.23 \pm 1.45$ & $87.83 \pm 1.83$ & $104.46 \pm 2.13$ & $121.07 \pm 2.50$ & $79.40 \pm 2.41$ & $98.27 \pm 3.03$ & $117.23 \pm 3.61$ & $136.10 \pm 4.16$ \\
\hline S.N.F. (g/kg) & $44.67 \pm 0.20$ & $55.60 \pm 1.41$ & $66.83 \pm 1.92$ & $78.40 \pm 2.19$ & $56.33 \pm 2.03$ & $70.16 \pm 2.61$ & $84.33 \pm 3.18$ & $98.5 \pm 3.15$ \\
\hline Protein $(\mathrm{g} / \mathrm{kg})$ & $28.17 \pm 0.72$ & $35.23 \pm 0.90$ & $42.27 \pm 1.10$ & $49.33 \pm 1.24$ & $27.50 \pm 0.28$ & $36.37 \pm 0.38$ & $41.27 \pm 0.43$ & $48.13 \pm 0.49$ \\
\hline Fat $(\mathrm{g} / \mathrm{kg})$ & $21.66 \pm 0.88$ & $27.33 \pm 1.20$ & $32.67 \pm 1.45$ & $37.67 \pm 1.45$ & $19.0 \pm 0.57$ & $24.0 \pm 0.57$ & $28.67 \pm 0.88$ & $33.33 \pm 0.88$ \\
\hline Ash (g/kg) & $6.07 \pm 0.03$ & $6.37 \pm 0.03$ & $6.70 \pm 0.00$ & $7.03 \pm 0.03$ & $5.05 \pm 0.07$ & $5.33 \pm 0.09$ & $5.7 \pm 0.15$ & $6.06 \pm 0.06$ \\
\hline Acidity (\%) & $0.12 \pm 0.00$ & $0.15 \pm 0.00$ & $0.19 \pm 0.00$ & $0.24 \pm 0.01$ & $0.11 \pm 0.01$ & $0.13 \pm 0.01$ & $0.16 \pm 0.00$ & $0.005 \pm 0.00$ \\
\hline $\mathrm{pH}$ & $6.6 \pm 0.0$ & $6.6 \pm 0.0$ & $6.8 \pm 0.0$ & $6.4 \pm 0.0$ & $6.7 \pm 0.0$ & $6.7 \pm 0.0$ & $6.7 \pm 0.0$ & $6.7 \pm 0.0$ \\
\hline
\end{tabular}

Table 6. Continued

\begin{tabular}{|c|c|c|c|c|c|c|}
\hline \multirow{2}{*}{ Sources of variation } & \multicolumn{4}{|c|}{ Types of soymilk } & \multirow{2}{*}{ SED value } & \multirow{2}{*}{ L.S } \\
\hline & C1 & $\mathrm{C2}$ & C3 & $\mathrm{C} 4$ & & \\
\hline Moisture (g/kg) & $931.77 \pm 1.45$ & $915.57 \pm 1.85$ & $899.07 \pm 2.13$ & $882.87 \pm 2.50$ & 1.05 & NS \\
\hline S.N.F. (g/kg) & $46.00 \pm 1.15$ & $57.50 \pm 1.25$ & $68.90 \pm 1.90$ & $80.53 \pm 2.25$ & 0.89 & NS \\
\hline Protein $(\mathrm{g} / \mathrm{kg})$ & $25.33 \pm 0.88$ & $31.67 \pm 1.12$ & $38.00 \pm 1.32$ & $44.33 \pm 1.56$ & 0.39 & NS \\
\hline Fat $(\mathrm{g} / \mathrm{kg})$ & $18.66 \pm 0.33$ & $23.67 \pm 0.33$ & $28.0 \pm 0.57$ & $32.67 \pm 0.33$ & 0.36 & NS \\
\hline Ash (g/kg) & $4.57 \pm 0.07$ & $4.80 \pm 0.10$ & $5.4 \pm 0.07$ & $5.63 \pm 0.06$ & 0.03 & NS \\
\hline Acidity (\%) & $0.08 \pm 0.00$ & $0.12 \pm 0.00$ & $0.15 \pm 0.01$ & $0.16 \pm 0.01$ & 00 & NS \\
\hline $\mathrm{pH}$ & $6.7 \pm 0.0$ & $6.6 \pm 0.0$ & $6.6 \pm 0.0$ & $6.5 \pm 0.0$ & - & NS \\
\hline
\end{tabular}

Means with different superscript in the same row differ significantly $(\mathrm{p}<0.05), *=5 \%$ level of significance and $* *=1 \%$ level of significance. 


\subsubsection{Protein Content}

The average proteins content of A, B and C type soymilk were $38.75 \pm 4.5, \quad 37.81 \pm 4.44$ and $34.83 \pm 4.08 \quad(\mathrm{~g} / \mathrm{kg})$ respectively (Table 4). There was significant difference among the protein content of different types of soymilk samples. Highest score was obtained in A type soymilk. Protein content of $100,125,150$ and $175 \mathrm{~g}$ concentration soymilk (i.e. 1, 2, 3 and 4) were $27.00 \pm 0.85,33.75 \pm 1.07$, $40.51 \pm 1.28$ and $47.26 \pm 1.50(\mathrm{~g} / \mathrm{kg})$ respectively (Table 5). The effect of concentration level on protein content of soymilk was also significant. Average protein content of different types of soymilk with different concentration are shown in Table 6.Protein content of soy milk was studied by different researchers. Shikder [9] found that protein content of soymilk was $3.08 \%$.Plernchai [8] found $2.8 \%$ protein in soymilk.

\subsubsection{Fat Content}

The average fats content of A, B and C type soymilk were $29.83 \pm 2.33,26.25 \pm 3.07$ and $25.75 \pm 2.99(\mathrm{~g} / \mathrm{kg})$ respectively (Table $4 \& 5$ ). There was significant difference among the fat content of different type of soymilk samples. From this result it was observed that A type soymilk had highest fat content. On the other hand fat content of 100, 125, 150 and $175 \mathrm{~g}$ concentration soymilk (i.e. 1, 2, 3 and 4) were $19.78 \pm 0.94$, $25.00 \pm 1.17,2978 \pm 1.45$ and $34.56 \pm 1.57(\mathrm{~g} / \mathrm{kg})$ respectively. The effect of concentration level on fat content of soymilk was also significant. The interaction effects of method and concentration level were non-significant. Average fat content of different types of soymilk with different concentration are shown in Table 6. Fat content of soymilk was studied by several researchers. The fat content of the present experiment agree with the findings of [9].

\subsubsection{Carbohydrate Content}

The average carbohydrates content of A, B and C type soymilk were $20.97 \pm 2.54,38.14 \pm 4.47$ and $26.99 \pm 3.21(\mathrm{~g} / \mathrm{kg})$ respectively (Table 4). There was significant difference $(p<0.05)$ among the carbohydrate content of different type of soymilk samples. Carbohydrate content of B type soymilk was significantly higher than A and $\mathrm{C}$ type soymilk. This might be due to hull content of B type soymilk. On the other hand carbohydrate content of $100,125,150$ and $175 \mathrm{~g}$ concentration soymilk (i.e. 1, 2, 3 and 4) were 20.94 \pm 3.66 , $25.86 \pm 4.65,31.31 \pm 5.49$ and $36.7 \pm 6.31(\mathrm{~g} / \mathrm{kg})$ respectively (Table 5). The effect of concentration level on carbohydrate content of soymilk was also significant. Average Carbohydrates of different types of soymilk with different concentration are shown in Table 6.

\subsubsection{Ash Content}

The average ash content of A, B and C type was $6.54 \pm 0.21$, $5.55 \pm 0.22$ and $5.10 \pm 0.25(\mathrm{~g} / \mathrm{kg})$ respectively (Table 4$)$. There were significant differences $(\mathrm{p}<0.01)$ among the ash content of A, B and C type soymilk. Ash content was significantly increased in A type soymilk. A type milk was most preferable. Ash content of 100, 125, 150 and $175 \mathrm{~g}$ concentration soymilk (i.e. 1, 2, 3 and 4) was $5.24 \pm 0.44$, $5.5 \pm 0.46,5.9 \pm 0.39$ and $6.24 \pm 0.41(\mathrm{~g} / \mathrm{kg})$ respectively (Table $5)$. The effect of concentration level on ash content of soymilk was also significant.

\subsubsection{Acidity Percentage}

The percentage of acidity of A, B and C type soymilk were $0.17 \pm 0.020,0.15 \pm 0.02$ and $0.13 \pm 0.02$ respectively (Table 4 ). There was significant difference among A, B and C type soymilk. Acidity percentages of 100, 125, 150 and 175 gconcentration soymilk were $0.10 \pm 0.02,0.133 \pm 0.00$, $0.17 \pm 0.12$ and $0.20 \pm 0.02$ respectively (Table 5). Significant difference was in concentration level.

\subsection{9. pH Value of Different Soymilk Samples}

The $\mathrm{pH}$ value of A, B and C type soymilk were $6.6 \pm 0.08$, $6.7 \pm 0.0$ and $6.6 \pm 0.04$ respectively (Table 4 ). There was no significant difference among $\mathrm{A}, \mathrm{B}$ and $\mathrm{C}$ type soymilk. $\mathrm{PH}$ value of $100,125,150$ and $175 \mathrm{~g}$ concentration soymilk (i.e. 1, $2,3$ and 4$)$ were $6.6 \pm 0.03,6.6 \pm 0.03,6.7 \pm 0.05$ and $6.5 \pm 0.09$ (Table 5). No significant difference was found within concentration. The interaction effects of method and concentration level were non-significant. Average $\mathrm{pH}$ values of different types of soymilk with different concentration are shown in Table 6.

\section{Conclusions}

From the statistical analysis significant difference was found in dehulled soy seed blending milk (A), whole soy seed powder milk (B) and sundry dehulled soy seed powder milk (C) type soymilk but no significant difference was found between A and Btype soymilk sample. So, we can accept either A type or B type milk. On the basis of 100 , 125,150 and $175 \mathrm{~g}$ concentration soymilk, the highest score was found for $125 \mathrm{~g}$ concentration soymilk. And highest score was obtained in dehulled soy seed blending milk of 125 concentrations sample (A2).Chemical analysis showed that total solids, solids not fat content, protein, fat, carbohydrate, ash, $\mathrm{pH}$ and acidity value increased with increased concentration of soybean and the moisture content decreased with increased concentration of soybean. From the results of chemical parameters significant difference was observed within $\mathrm{A}, \mathrm{B}$ and $\mathrm{C}$ in terms of moisture content, total solids content, solids not fat content, protein content, fat content, carbohydrate content and acidity percentage. Statistical analysis showed that moisture, protein, fat, and ash content are significantly higher in A type soymilk. B type milk contains more carbohydrate because this type of milk was prepared from soy seed containing hull. On the other hands, it is evident that nutrient contents increase with the increase of concentration of soymilk. But after boiling it is found that 150 and $175 \mathrm{~g}$ concentrate soymilk become thicker which had less acceptability by the judges. Judging from the results of all parameters dehulled soy seed blending milk with 125 gconcentration may be recommended for consumption. 
Saeed et al. [10] stated that dehulled soybean milk is more nutritious as compared to whole soybean milk.

\section{Acknowledgment}

This paper is the result of a project work sponsored by Department of Dairy Science, Bangladesh Agricultural University, Mymensingh.

\section{References}

[1] Rakhi TA, Islam MN, Hoque SAM, Rahman MM. Development of mango flavored Soy Dahi. Bangladesh Journal of Animal Science. 42, 2013, p. 44-48.

[2] Rahman L. Cultivation of soybean and its uses. The city press. Dhaka. 1982, p.5-7.

[3] Li J, Hsieh YHP. Traditional Chinese food technology and cuisine. Asia Pacific Journal of Clinical Nutrition. 13, 2004, p. $147-155$.

[4] Kaul AK, Das ML. Oil seed in Bangladesh, Ministry of Agriculture, Dhaka, 1986.

[5] Anderson JJB, Adlercreutz H, Barnes S, Bennink MR, et al. Appropriate is flavones food fortification levels: Results of consensus conference, Univ. of No. Carolin Helsinki, Ala, Birmingham, Michigan St., Minnesota, Iowa St., Cincinnati, Purdue and Illiors; San Diego CA April, 2000, p. 15-18.

[6] AOAC, Association of Official Agricultural Chemists. Official Methods of Analysis. 10 ${ }^{\text {th }}$ Edition. Washington, DC, USA, 2003.

[7] Escueta EE, Banzon JA, Comparative acceptability of soymilk produced by different processing methods. Philippine. Journal of Science, 108 (1\&2), 1979, p. 55-63.

[8] Plernchai. Application of Soybean and Soybean Products in Thailand. Nutrition and Health Department, Institute of Food Research and Product Development, Kasetsart University, 2000.

[9] Shikder FH. Evaluation of nutritive value and shelf life of soymilk. Department of food Technology and Rural Industries, Bangladesh Agricultural University, Mymensingh, 2003.

[10] Saeed SN, Almas K, Bhatty N, Hashmi AS, Biological evaluation of whole soymilk produced by indigenous soybean. Pakistan Journal of Scientific and Industrial Research, 44 (6), 2001, p. 356-360.

[11] Kim JH, Lee HJ, Characteristics of cheese manufactured by co-precipitation of whey and soya milk. Soybean abstract. 9 (11), 1985, p. 306. 